\title{
КОЛЕСО ИСТОРИИ
}

https://doi.org/10.30932/1992-3252-2019-17-3-260-277

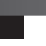

\section{Зарождение системы управления} путями сообщения и транспортного законодательства России в IX-XVIII веках

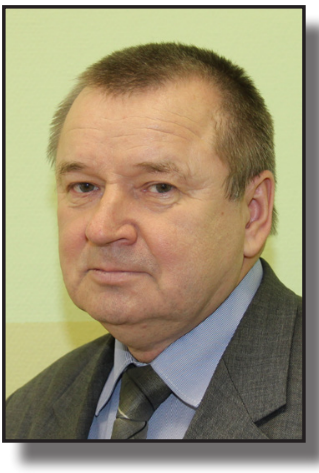

Юрий ПЕТРОВ

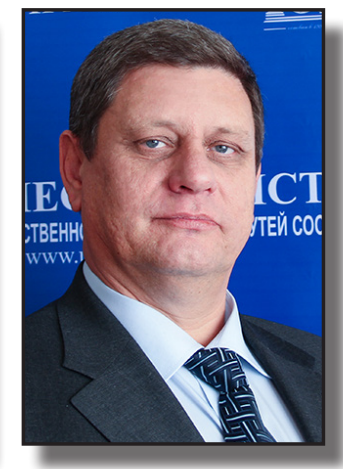

Александр ЗЕМлИН

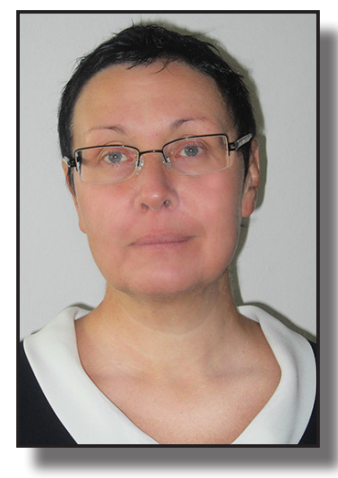

Ольга ЗЕМЛИНА

Петров Юрий Иванович - Российский университет транспорта, Москва, Россия. Землин Александр Игоревич - Российский университет транспорта, Москва, Россия. Землина Ольга Михайловна - Российский университет транспорта, Москва, Россия.

В статье проанализированы российские историкоправовые памятники, содержащие нормы, регулирующие общественные отношения, возникавшие в процессе становления водного и сухопутного дорожного дела, развития транспортныхкоммуникаций, формирования государственного управления транспортной сферой.

Предметом исследования выступили важнейшие нормы российского транспортного законодательства.

Целью исследования было научное изучение опыта правового регулирования транспортных отношений в исторический период с IX по XVIII век в целях выявления основных этапов развития и периодизации отечественного транспортного права.

Исследование осуществлено с использованием методов правового анализа, в том числе формально-догматического, позволившего вскрыть отдельные недостатки и пробелы правового регулирования, историко-правового, который в сочетании с приёмами таксономического анали- за сделал возможным осуществление авторской периоди зации становления транспортного законодательства в исследуемый период. Использование достижений правовой герменевтики и инструментария лингво-семиотического и семантического подходов обеспечили возможность уяснения содержания правовыхнорм июридическихдокументов, относящихся к рассматриваемому периоду.

Результаты исследования представляют интерес с точки зрения выявления исторических закономерностей развития транспортного права, дают возможность оценить роль и место транспортного законодательства в системе правовых регуляторов общественных отношений. Представленные научные результаты с учётом уже имеющихся и практически фундированных наработок могут послужить отправной точкой для дальнейшей дискуссии о перспективах, тенденциях и направлениях развития российского транспортного права и транспортного законодательства.

Ключевые слова: транспорт, транспортное законодательство, историко-правовой анализ, исторические этапы, пути сообщения.

*Информация об авторах:

Петров Юрий Иванович - кандидат исторических наук, доцент, доцент кафедры таможенного права и организации таможенного дела Российского университета транспорта, Москва, Россия, Petrov52@ro.ru.

Землин Александр Игоревич - доктор юридических наук, профессор, заведующий кафедрой транспортного права Российского университета транспорта, Москва, Россия, kafedratp@mail.ru. Землина Ольга Михайловна - кандидат юридических наук, доцент кафедры транспортного права Российского университета транспорта, Москва, Россия, kafedratp@mail.ru.

Статья поступила в редакцию 02.04.2019, принята к публикации 16.05.2019.

For the English text of the article please see p. 270. 
B опросы правового регулирования транспортных отношений во все времена относились к числу имевших самое существенное значение для экономического и социального развития государства и общества, что с необходимостью детерминировано ролью и значением транспорта. Транспорт, хотя и не создаёт новых предметов материального мира, является необходимым условием обеспечения нормального функционирования отраслей экономики и торговли. Поскольку продукция транспорта как отрасли материального производства - это деятельность по территориальному перемещению грузов или людей, постольку транспорт является связующим звеном экономики страны, охватывающим все виды общественного производства, распределения и обмена. Транспортные отношения находятся в тесной связи с другими социально-экономическими отношениями, что во многом определяет их природу, а также потребность в их полном и ригоричном регулировании с использованием правовых норм.

Очевидно, что адекватно и полно познать какое-либо социальное явление возможно только через изучение его исторических корней, исследование его генезиса.

Профессор права Московского университета А. Н. Филиппов определял задачу историко-правового подхода к юридическим исследованиям следующим образом: «Какое бы юридическое понятие мы ни взяли в истории..., каждое из них пережило длинный ряд изменений, прежде чем предстало перед нами в том развитом и расчленённом образе, в каком оно является в современных юридических теориях или законодательствах различных стран. Над видимым хаосом беспорядочной смены одних юридических норм и учреждений другими царит, в действительности, строгая последовательность правовых явлений, причинная зависимость одних от других, преемственность их развития» [1, с. 231-232].

Вопросам исследования истории становления и развития транспорта в России посвящено немало работ, вышедших из-под пера известных представителей научного сообщества и государственных деятелей - С. Ю. Витте, А. А. Головачова, С. М. Житкова, И. М. Рабиновича,
Н. А. Кислинского, П. П. Мигулина, И. Х. Озерова, А. И. Чупрова, А. С. Сенина, Д. Ю. Левина, А. В. Постникова и многих других. При этом предметом исследования одних являлись общеисторические сведения, попутно затрагивающие транспортную проблематику, иных - непосредственно вопросы, посвящённые истории транспорта, чаще всего железнодорожного.

Вместе с тем имеется явный дефицит внимания к научным исследованиям указанной проблемы со стороны специалистов в области юриспруденции. Предметом исследования учёных-юристов становились только отдельные временные этапы становления и развития транспортного законодательства, регулирующего общественные отношения, связанные с конкретными отраслями транспорта.

Тем не менее результаты имеющихся немногочисленных историко-правовых исследований, имеющих комплексный характер, свидетельствуют о том, что правовому регулированию и организации транспортной деятельности в России во все времена придавалось особое значение, предопределённое их значением для развития экономики и обороны страны [2, c. 5-32].

В ходе нашего исследования мы постарались выделить основные этапы зарождения и развития транспортного права, ориентируясь, в первую очередь, на сферу правового регулирования государственного управления путями сообщения или, выражаясь современным языком, транспортной инфраструктурой, не останавливаясь на детальном анализе законодательства, регулирующего перевозочный процесс, осуществляемый различными видами транспорта, что в год 210-летия единого транспортного ведомства несомненно будет освещено в других публикациях.

\section{ЗАРОЖДЕНИЕ ТРАНСПОРТНОГО ЗАКОНОДАТЕЛЬСТВА В ДРЕВНЕЙ Руси}

Ещё до создания древнерусского государства появились транспортные линии, по которым осуществлялись торговые отношения племенных союзов, в основном это были водные пути. Дальнейшее разви- 


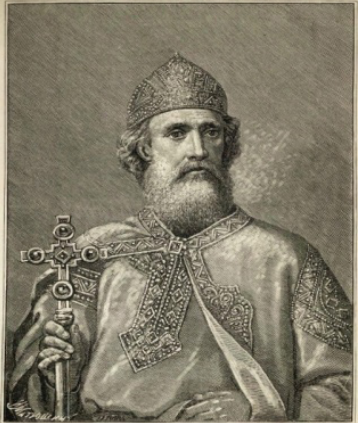

Владимир I Святославич (др.-русск. Володимеръ Сватславь (ок. 960-1015)) - Киевский великий князь.

тие путей сообщения привело к зарождению и становлению транспортного законодательства в Древней Руси.

Русские князья издревле начали заботиться об устройстве дорог и мостов и вообще о путях сообщения, правда, вначале руководствуясь военными соображениями.

В летописи 1014 года сказано: «и рече Володимер требите путь и мостите мосты хотяшеть бо на Ярослава ити"» [3, с. 36]. Такие сборы, как мостовщина ${ }^{* *}$ и перевоз $^{* * *}$, принадлежащие к числу древнейших торговых пошлин, обеспечивали работы по строительству и эксплуатации дорог и мостов. Кроме того, мостовщина выступала и как повинность, лежавшая на населении и состоявшая в устройстве мостов через реки, а также деревянных настилов на улицах населённых пунктов и дорог вообще. Древнейшее известие о ней содержится в Русской Правде в редакции XI века [4, c. 154].

Принятый в 60-е годы XIII века «Устав князя Ярослава о мостех» [5, с. 236-238] содержал нормы по организации мощения главных торговых магистралей Новгорода и дорог, ведущих к пристаням и к месту городской торговли. Уставом устанавливались развёрстка для населения мостовой повинности, порядок организации строительства и ремонта моста через Волхов и доставки сплавом строительных материа-

* Здесь и далее - цитаты из некоторых исторических правовых актов, названия документов и органов управления приводятся в изначальном написании прим. ред.

** Мостовшина - пошлина взималась за проезд через мост.

*** Перевоз - пошлина взималась при переправе через реку.

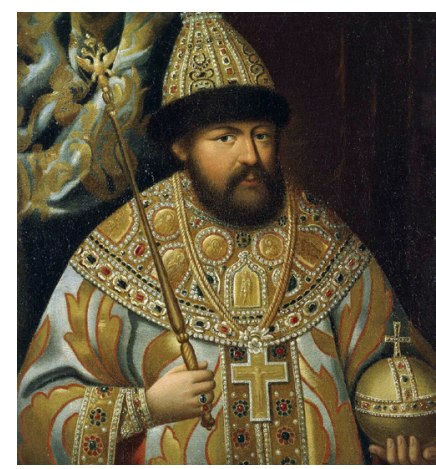

Алексей I Михайлович, прозванный Тишайшим (1629-1676) - десятый Царь всея Руси. Годы правления: 1645-1676 гr.

лов для мощения торговых проездов и ремонта мостов.

\section{СТАНОВЛЕНИЕ ТРАНСПОРТНОГО ЗАКОНОДАТЕЛЬСТВА В МОСКОВСКОМ ГОСУДАРСТВЕ (XVI-XVII BEKA)}

Столетиями устройство мостов и перевозов из-за недостатка средств у правительства осуществлялось как личная повинность граждан. Такая практика сохранялась ещё и в XVI веке. Например, грамотой 1596 года было установлено, что мосты на малых речках, пострадавшие во время весеннего разлива, должны ремонтироваться «ближними сохами», то есть, крестьянами. О повинности мостить мосты упоминается также и во многих жалованных грамотах.

В первой половине XVII века наблюдался заметный рост ремёсел, торговли, складывался единый рынок страны. Эти процессы сделали в значительно большей мере, чем в предшествующие годы, необходимым государственно-правовое регулирование режима внутренних путей сообщения и их финансового обеспечения.

В середине XVII столетия заметно возросла законодательная деятельность Московского государства, усилилось стремление правительства подвергнуть правовой регламентации всё больше сторон и явлений общественной и государственной жизни. Венцом правотворческой деятельности стало создание Соборного уложения 1649 года.

Дорожное правовое регулирование, сложившееся к этому времени, получило в нём наиболее полное выражение. Главу IX Уложения «О мытах, и о перевозах, и о мо- 
стах» составили нормы двух направлений регулирования общественных отношений: регламентация сбора проезжих пошлин и обеспечение сохранности и благоустройства дорог, мостов и перевозов. Объединение их в одной главе ясно показывало, для чего в своё время были введены проезжие пошлины - для поддержания в порядке путей сообщения.

Использование существовавших водных путей также нашло своё правовое урегулирование в Уложении. В нём приведены правила для внутреннего речного судоходства. Сообщение по рекам издревле сталкивалось с трудностями естественного характера, вызванными природными явлениями. Однако с развитием гидростроительства стали создаваться и серьёзные искусственные затруднения. Уложение установило: «а которыми реками суды ходят, и на тех реках прудов новых и плотин и мельниц не делати, чтобы по тем рекам новыми прудами и плотинами ходу не переняти» [6, с. 98], устранив таким образом препятствия для навигации.

\section{РАЗВИТИЕ ТРАНСПОРТНОГО ЗАКОНОДАТЕЛЬСТВА В ПРАВЛЕНИЕ ПETPA I}

Постепенно сложившиеся в России к середине XVII века организация дорожного дела и правовой статус дорог не привели тем не менее к систематической деятельности по управлению этой сферой. Коренные изменения стали происходить в правление Петра Великого, который, по мнению В. О. Ключевского, вернулся из своего первого путешествия из-за границы с представлением о Европе как «шумной и дымной мастерской с машинами, кораблями, верфями, фабриками, заводами» [7, c. 25]. Очевидно, что такой же царь захотел увидеть и Россию.

Проявляя заботу о развитии торговли и промышленности, Пётр начал первые работы по устройству водных и сухопутных путей сообщения. Водная сеть внутри государства развивалась посредством строительства каналов. Выходившие в это время распоряжения демонстрируют его усилия, направленные на просвещение русского купечества и становление торгового мореплавания.

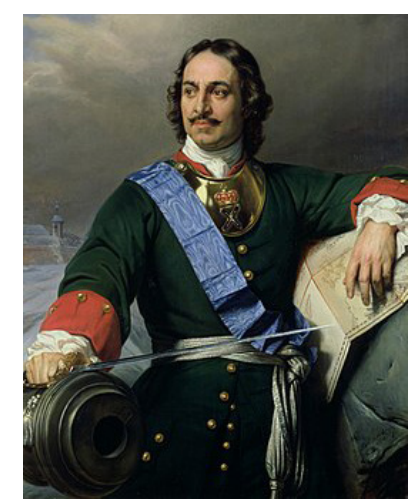

Пётр I Алексеевич, прозванный Великим (16721725) - последний Царь всея Руси (с 1682 года) и первый Император Всероссийский (с 1721 года).

Активная практическая деятельность по сооружению водных транспортных путей способствовала ускорению развития российского морского законодательства, свидетельством чему явилось принятие 26 июля 1720 года Устава о эверсах ${ }^{* * * *}$. Устав детально регламентировал взаимоотношения хозяина судна и грузоотправителя, устанавливал время погрузки и разгрузки, а также распределял издержки на погрузку и разгрузку. Возмещение ущерба при повреждениях, понесённых эверсом, возлагалось на хозяина судна, а убытки, связанные с товарами, нёс купец [8, с. 219]. В 1724 году вышел морской торговый устав, установивший порядок досмотра торговых кораблей, предъявления перечня товаров с ценами на них, а также наложения взысканий за несоблюдение уставных правил.

Не осталось без внимания Петра I и сухопутное сообщение. Сооружались грунтовые дороги, в частности, от Петербурга до Москвы и от Москвы до Азова. В 1711 году на тракте Москва-Санкт-Петербург были устроены почтовые станции в Волоколамске, Ржеве, Старой Руссе [9, с. 84]. В отношении станций законодательно закреплялся порядок, касающийся проезжих лиц и работников. Движение по трактам также становилось упорядоченным и подчинялось складывающимся правилам писанным и не писанным, которые пронизывали разные стороны дорожного быта.

При Петре I началось сооружение сухопутной дороги от Москвы до Волхова, ставшее первым опытом современного дорожного строительства. В сенатском

**** Эверс - большая речная лодка. 


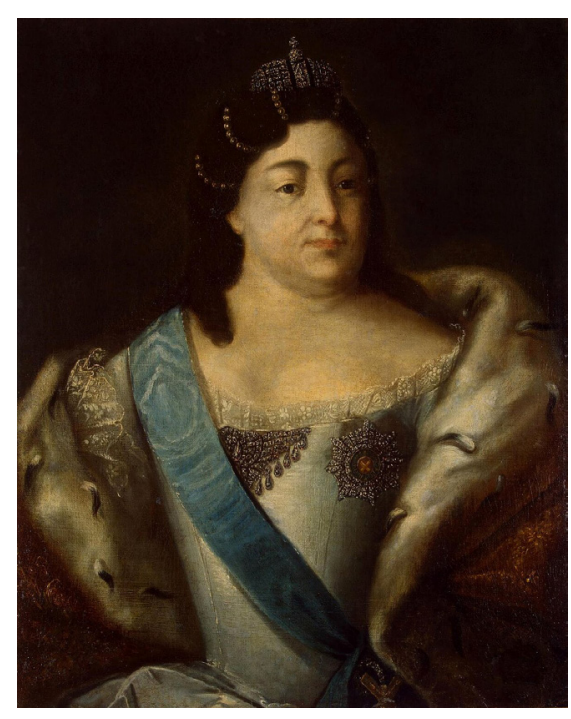

Анна Иоанновна (Анна Ивановна) (1693-1740) российская императрица из династии Романовых. Годы правления: 1730-1740.

указе от 1 июня 1722 года «О постройке новой дороги от Волхова до Москвы и о сборе для сего денег с купечества и крестьянских дворов, против канального расположения» были определены порядок строительства, время его осуществления и силы, которые для него привлекались. В дорожных работах участвовали люди, «которые живут от дороги даже до 50 вёрст в стороны», работы выполнялись в «сухое время, чтобы только коренья выкопали», мостить же и рвы копать должны были «в осень, когда от полевой работы отделаются» [10, с. 716-717].

В созданной в 1717 году Петром коллежской системе органов исполнительной власти руководство сферой транспорта было возложено на Коммерц-коллегию, наделённую полномочиями по разработке транспортно-правовых актов. Ведая торговым делом, которое самым непосредственным образом было связано с дорогами, Коллегия должна была обеспечивать и беспрепятственное перемещение по ним. Пётр поручил ей создать необходимые условия для торговой деятельности купечества, и так как основные пути сообщения были морскими и речными, то и торговый флот с хорошо обученными командами стал её заботой. Коллегии вменялось контролировать производство работ по развитию водных сообщений и по строительству сухопутных дорог.

\section{TPAНСПОРТНОЕ ЗАКОНОДАТЕЛЬСТВО В ЭПОХУ «ДВОРЦОВЫХ ПЕРЕВОРОТОВ"}

После смерти Петра I в январе 1725 года, в экономике государства наблюдался некоторый спад, отразившийся и на развитии путей сообщения. Однако и новые правители не оставляли без внимания дорожное строительство, выделяя средства на ремонт старых и сооружение новых дорог, а также строительство водных путей, при необходимости предоставляя и рабочую силу из воинских гарнизонов. Например, в 1735 г. для выполнения текущих работ на Ладожском канале был сформирован рабочий батальон, размещенный вблизи объекта. В 1740 г. инженер-подполковник Людвиг обратился в правительство с рапортом о выделении батальону кроме обер- и унтер-офицеров ещё 78 рядовых и 26 денщиков, требующихся для выполнения указания генерал-фельдмаршала графа Миниха обеспечить качественное и безопасное содержание канала. Полковник просил дополнительный контингент из рекрутов, но кабинет министров указал Военной коллегии пополнить батальон отставными из полевых полков, при этом сделать так, чтобы батальон при Ладожском канале был расселен в своих домах, а солдатских жен и детей перевести из мест их проживания к мужьям и в дальнейшем руководствоваться этим правилом [11, c. 65].

Учреждённая Петром Великим в 1717 г. Камер-коллегия в правление Анны Иоанновны была реорганизована и 23 июня 1731 г. получила новый регламент, в целом сузивший её функции. У ведомства, как и прежде, остался надзор за всеми доходами государства, но добавился контроль за состоянием больших дорог посредством губернаторов и воевод [12, с. 168-169]. В уездах они должны были обеспечивать их пригодность для проезда. В тех случаях, когда требовался ремонт дорог, а также починка мостов, то им разрешалось привлекать население, но не в горячую рабочую пору.

В правление Анны Иоанновны, в марте 1731 г., вышел сенатский указ «О починке по Санкт-Петербургской и Псковской дорогам мостов из казны, об отпуске на сиё потребной суммы и об употреблении на 
починку перспективной дороги от Волхова до Санкт-Петербурга несколько рот из гарнизонных полков» [13, с. 392-393].

Указ определил места, в которых должны были быть построены мосты и переправы, а также материалы, используемые для этих целей. Ограниченность средств казны требовала рационального их использования, поэтому на пространстве от Новгорода до перспективной дороги (Санкт-Петербург-Москва) для «почтовой гоньбы» ремонт мостов и переправ предусматривалось производить только в самых необходимых точках. Также и дорогу от Волхова до Санкт-Петербурга можно было ремонтировать только в местах, строго определённых графом Минихом с выделением для работ нескольких рот из гарнизонных войск. На дорожные работы и заработную плату строителям были отпущены 10 тыс. руб. из Полицеймейстерской канцелярии Санкт-Петербурга, а также часть поступающих в казну акцизных сборов. В случае недостатка средств предлагалось обращаться в Сенат. Что же до леса, необходимого для строительства мостов, то, по расчётам московских дорожных осмотрщиков, требовались тысячи деревьев, которые могли быть взяты на дачах помещиков, а также в дворцовых и синодальных вотчинах. Лес рекомендовалось использовать на мостах и переправах в самых необходимых местах, «дабы напрасной траты леса не было». Учитывая это обстоятельство, из казны сверх вышеназванной суммы выделялось ещё 4000 рублей.

Для активизации работ по сооружению тракта в 1733 году была создана Канцелярия перспективной дороги, тогда же вышли Правила строительства дорог, мощения фашинами в болотистых местах. Канцелярия стала первым специализированным органом, непосредственно занимавшимся путями сообщения. Она подчинялась $\mathrm{Ce}$ нату, а её содержание осуществлялось за счёт средств, получаемых с пользователей дорог [14, с. 223].

В конце 1733 году в Кабинет императрицы Анны Иоанновны поступило донесение от графа фон Вейсбаха, находившегося в это время на службе у русского правительства. В нём сообщалось «о худой дороге от Клина до Москвы и около Тулы и Курска». Это донесение было передано в Правительствующий сенат для рассмотрения. В результате в январе 1734 года вышел сенатский указ «О починке мостов и перевозов». Поскольку за состояние дорог в России в этот момент в большей мере отвечала Камер-коллегия, то ей и были даны соответствующие указания. Во-первых, мосты и перевозы, отданные на откуп, должны были быть освидетельствованы, и откупщики, хозяева «худых мостов», принуждены выполнить ремонтные работы «в удобное время» и впредь содержать данные объекты в исправном состоянии. Во-вторых, по мостам и перевозам, которые содержались на вере, Камер-коллегией незамедлительно должно было быть принято решение «о строении и починке тех мостов». В-третьих, по дорогам, ремонт которых осуществлялся государством, требовалось составить опись, указав участки, на которых необходимо выполнить ремонтные работы, определить потребность в материалах и в рабочей силе «конной и пешей» и как далеко от дорог находятся леса. Эксперты, осуществлявшие вышеназванные мероприятия, должны были внести предложения «каким-то лучшим порядком без дальнего казённого убытку и народной тягости исправить будет можно», а соответствующую опись по работам и смету на них направить в Камерколлегию, а та, после рассмотрения, в Сенат, сопроводив её собственными соображениями. В заключительной части указа отмечалось: «а где через реки и ручьи в чьих сёлах и деревнях мосты в худом состоянии находятся, тех сёл жителей, чьи б они ни были, строить и починивать принудить немедленно, как о том указы повелевают, и смотреть накрепко, чтобы проезжающим в тех местах остановки не было» [15, с. 258-259].

Таким образом, очевидно, что правовые меры, принятые правительством Анны Иоанновны, были направлены на развитие внутреннего судоходства, дорожного строительства, улучшение ремонтных работ, на совершенствование управления отраслью в центре и на местах и, что особенно важно, на заботу о купечестве и населении, привлекаемом к работам в дорожном деле.

В последовавшее правление Елизаветы Петровны правовое регулирование дорож- 


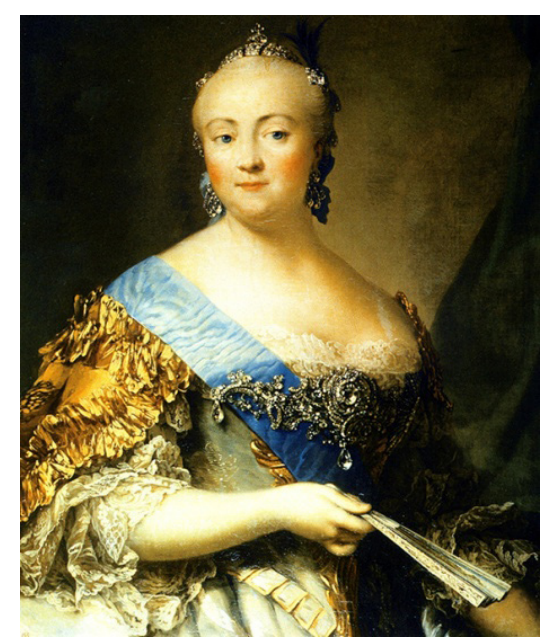

Елизавета Петровна Романова (1709-1761) российская императрица из династии Романовых. Годы правления: 1741-1762.

ного строительства и эксплуатации сухопутных дорог получило дальнейшее развитие.

В 1744 году было предписано не допускать зарастания московской дороги деревьями. Владельцам поместий вменялось в обязанность очищать расположенные вблизи участки дорог. Во всех губерниях большие дороги с целью обеспечения свободного и безопасного проезда должны были очищаться от деревьев в обе стороны на 15 сажень. По аналогии с московской дорогой каждому помещику поручалось напротив своих дач освобождать от деревьев придорожные участки [9, с. 184-185].

В 1754 году с началом таможенной реформы, предусматривавшей, в том числе, уничтожение внутренних сборов, было подтверждено, что дороги остаются в ведении губернаторов и воевод, которые должны обеспечивать их исправное состояние и при необходимости привлекать к ремонтным работам население.

Канцелярия перспективной дороги в 1755 году была переименована в Канцелярию от строения государственных дорог и стала органом, руководящим строительством и содержанием государственных дорог. Возглавил её главный судья, а непосредственными исполнителями распоряжений Канцелярии оставались воеводы $[14$, c. 221$]$.

В 1760 году последовало указание, запретившее осуществлять ремонтные работы с привлечением населения на дороге между столицами, и теперь это должны были делать наёмные работники. Безусловно, эта мера значительно облегчала положение проживавших вблизи дорог людей и способствовала повышению качества ремонтных работ.

Императрица Екатерина II уже в начале своего царствования обратила внимание на дорожное дело.

Указом «О приведении Государственных дорог в наилучшее состояние» от 18 февраля 1764 года руководителем Канцелярии от строения государственных дорог был назначен генерал-поручик Николай Муравьёв. Перед ним была поставлена задача «приводить все государственные дороги в наилучшее состояние», при этом он мог требовать помощи от Сената и даже непосредственно обращаться к императрице [16, c. 541]. Вскоре Канцелярия приобрела статус центрального учреждения, и местная власть губерний и провинций должна была регулярно перед ней отчитываться о состоянии дорог. В распоряжении Канцелярии находился строительный батальон, который комплектовался «рекрутами и всякими вступающими в службу разночинцами, способными к отправлению оной службы» [17, с. 152-153]. В течение длительного времени он решал многие вопросы строительства дорог, искусственных сооружений и их эксплуатации.

В 1775 году в результате реформы местных органов управления были учреждены казённые палаты, назначением которых являлось обслуживание фискальных интересов государства. Однако они вскоре вынуждены были заниматься и дорожным строительством. Следствием преобразований в местном управлении стало то, что вскоре указом от 24 октября 1780 года Канцелярия от строения государственных дорог была упразднена. Готовые дороги перешли в ведение исправников и нижних земских судов, а для незавершённых дорог были учреждены особые экспедиции при губернских казённых палатах [18, с. 994997]. В 1782 году был расформирован строительный батальон, Екатерина II в указе от 26 января мотивировала это тем, что «содержание дорог в исправности есть дело общественное, в котором Нижние Земские Суды наблюдением обязаны, а где по указам Нашим предписано их строить 
казённым иждивением, там все сии работы производимы суть подрядом» [19, с. 388].

Потребность в специализированном органе заставила в 1786 году создать новое дорожное учреждение - Комиссию о дорогах в государстве. Указ от 14 марта [20, c. 319-322] не делал акцента на необходимости хорошего содержания дорог, но отмечал, что они нужны «для обеспечения сообщения между различными местами государства, для доставления в жизни человеческой нужного, для пособия торговли, следовательно, и для блага общего». Комиссия должна была разработать генеральный план строительства дорог в России, получив предварительно из губерний дорожные карты с обоснованием целесообразности действующих и проектируемых к строительству дорог, а также сведения о материальных ресурсах, имеющихся на местах, и о потребности в строительстве мостов и отводных труб с примерными затратами на их сооружение.

Комиссия контролировала ход строительства дорог во всех губерниях, получая от экспедиций при губернских казённых палатах отчёты о выполненных работах и израсходованных средствах. Казённые палаты и казначейства на местах осушествляли непосредственный контроль за строительством, включая ревизии счётов и казённые взыскания.

Первым практическим опытом для Комиссии о дорогах в государстве должно было стать строительство дороги между Санкт-Петербургом и Москвой. Ей были переданы уже представленные на тот момент в Сенат планы и сметы по этому проекту.

Водные пути в правление Екатерины II также получили дальнейшее развитие, однако серьёзным препятствием для успешного ведения торговли русскими купцами являлось отсутствие правовой базы для осуществления судоходства. Так, в России не было устава купеческого водоходства, и это вынуждало русское купечество руководствоваться нормами законов иностранных государств. 1 июня 1781 года Устав [21, с. 157], наконец, был принят, и многие спорные вопросы получили в нём разрешение. Устав способствовал расширению торговых отношений внутри страны, за её пределами они осуществлялись

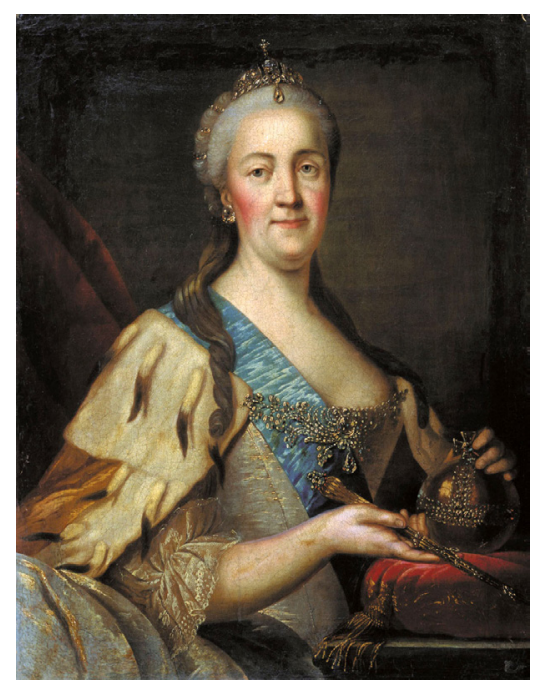

Екатерина Алексеевна Романова (Екатерина II Великая) (1729-1796) - российская императрица. Годы правления: 1762-1796.

на основе принятой в 1780 г. «морской конвенции для охранения нейтрального торгового кораблеплавания».

В 1781 г. была обнародована и вторая часть Устава купеческого водоходства [22, c. 312-336], содержавшая нормы, регулирующие страхование кораблей на случай кораблекрушения и порчи товаров. Однако поскольку в это время в России ещё не было страховых обществ (они появятся только в правление Николая I), хозяева судов вынуждены были страховать русские корабли и товары в иностранных страховых обществах, что создавало много неудобств.

В 1784 году для создания более надёжного плавательного средства для преодоления речных порогов правительством был объявлен своего рода конкурс и обещана награда [9, с. 50]. В Санкт-Петербурге на Неве была создана городская верфь, финансируемая казной для активизации постройки российских судов. Каждый мог на верфи строить большие и малые, морские и речные суда. Оснащать их разрешалось в любом месте на усмотрение хозяина судна и даже выписывать оборудование для этих целей из-за границы.

Черноморское Адмиралтейское правление получило право выдавать подданным российские флаги на торговые суда сроком не более 6 лет для плавания по Чёрному и другим морям. При этом выставлялось одно условие: эти лица, должны были быть 


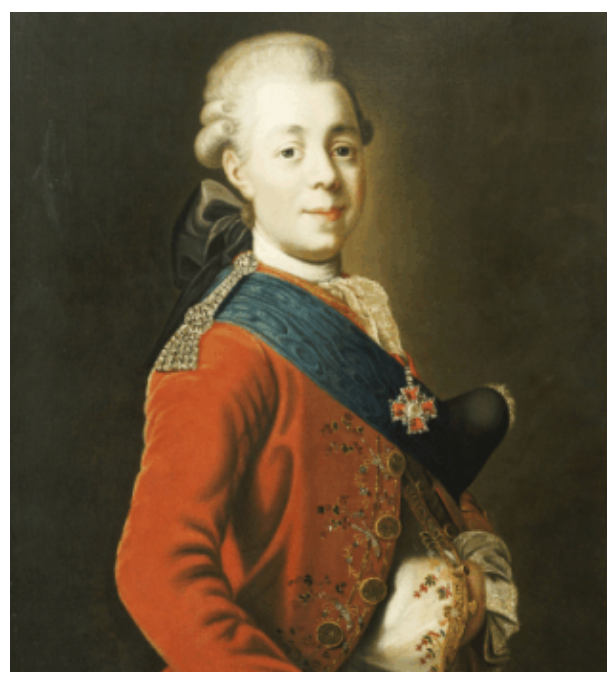

Павел I Петрович Романов (1754-1801) император Всероссийский. Годы правления: 1796-1801.

людьми известными и благонадёжными [9, c. 50-51]. Эти правительственные меры свидетельствовали о стремлении качественно улучшить речное и морское судоходство.

Павел I в своё короткое правление прежде всего обратил внимание на развитие водных путей сообщения и продолжил строительство каналов.

В 1797 году последовало указание соединить реки Днепр и Двину, используя реки Березину и Уллу, а также окончить каналы Огинский, предназначенный для соединения рек Припяти с Неманом, и Королевский, соединяющий реки Припять и Буг. В том же году, в ответ на просьбы купечества улучшить условия для судоходства, а также в целях обхода Ильменского озера, начали сооружение канала длиной в 8 вёрст из Мсты в Волхов. В 1798 году началось строительство канала, соединяющего реку Гавью с Двиной, с целью улучшения обеспечения доставки в Ригу товаров из окрестных мест. Стремлением ускорить строительство Вытегорского канала, который должен был соединить реки Ковжу и Вытегру, было обусловлено принятие в 1799 году решения заимствовать средства из Воспитательного дома по 400 руб. ежегодно. После завершения канал получил название Мариинского [9, с. 57-58].

В плане совершенствования государственного управления транспортом в 1797 году было принято решение о создании особого учреждения для заведования в империи путями сообщения, первоначально исключительно лишь водными. Указом Правительствующего Сената от 27 февраля 1797 года Главное управление водными коммуникациями возглавил тайный советник Я. Е. Сиверс. Через год, 28 февраля 1798 года, после принятия соответствующего положения, содержащего конкретные задачи, решение которых на него возлагалось, началась практическая деятельность этого учреждения. Главному управлению были переданы все водные сообщения Российской империи. Главное управление, в дальнейшем переименованное в Департамент водяных коммуникаций, просуществовало до 1809 года. В это время его возглавляли упомянутый граф Я. Е. Сиверс (1798-1800), затем граф Г. Г. Кушелёв (1800-1801), а последним его руководителем стал граф Н. П. Румянцев (1801-1809) [23, c. 59].

\section{выводы}

Вопросы устройства дорог и организации дорожного движения, развития водных коммуникаций, совершенствования государственного управления этими сферами, были в России изначально предметом внимания правителей и правового регулирования актами высшей юридической силы. При этом акты, являющиеся источниками транспортного права того периода, зачастую принимались в силу необходимости урегулирования внезапно возникающих проблемных ситуаций, в соответствии с субъективным восприятием правителями фактов объективной реальности и по их усмотрению. Нормы, регулирующие отношения в сфере организации путей сообщения, содержались в целом ряде правовых актов, подчас не имеющих непосредственного отношения к проблемам транспорта и подготовленных лицами, не представляющими в полной мере ни системы, ни принципов организации путей сообщения, ни тем более последствий вносимых «попутно» с решением различного рода конъюнктурных задач законодательных изменений, имеющих стратегическое значение.

Вместе с тем в XVI-XVII веках проявилась тенденция к регулированию правовых отношений «из центра». В принятом в 1649 г. 
Уложении наиболее полное выражение получило дорожное правовое регулирование. Основанием для укрепления правового статуса сухопутных и водных путей стал интерес государства, состоявший в необходимости облегчить передвижение по дорогам служилых людей и гонцов. К сожалению, интересы торгующего класса не были достаточно учтены, что негативно сказывалось на темпах развития торговли и ремесел. В Уложении встречается первый закон об охране судоходства.

Систематическая деятельность правительств в области дорожного дела начинается при Петре Великом с проявления заботы о развитии торговли и промышленности.

Предлагаемая нами периодизащия предполагает, что в петровский и послепетровский период произошли вместе с изменением государственных задач и изменения целей правового регулирования. Проявились попытки создать единые органы управления транспортом, но соотношение централизованных и децентрализованных функций ещё не было постоянным.

В 1717 г. Пётр I учредил ряд коллегий, среди которых Коммерц- и Камер-коллегия, в разной степени наделённые полномочиями по развитию водных сообщений и строительству сухопутных дорог.

Екатерина создала «комиссию о дорогах в государстве» и лично контролировала её работу. В правление Павла I впервые появилось особое ведомство путей сообщения - Департамент водных коммуникаций.

Наличие многочисленных, но противоречивых и несистематизированных правовых актов, равно как и отсутствие единого органа управления транспортом не позволяли решать вопросы развития путей сообщения должным образом. Организационное, правовое, научное и кадровое обеспечение транспорта не соответствовало более потребностям экономики, торговли, военной безопасности Российского государства, что влекло за собой становящиеся недопустимыми потери в экономической сфере и приобретающие потенциально катастрофический характер угрозы обороноспособности государства.

В начале XIX столетия всё более настоятельной и объективно необходимой становилась потребность системных преобразо- ваний всех сторон государственного управления, включая управление путями сообщения. Приближался период коренных изменений в системе правового обеспечения путей сообщения и транспортной деятельности, происшедших в период царствования императора Александра I.

\section{ЛИТЕРАТУРА}

1. Землин А. И. Опыт правового регулирования финансового обеспечения войск в годы Великой Отечественной войны. 60 лет Великой Победы: история, уроки, современность: Материалы межвузовской научной конференции, 19 апреля 2005 г. - М.: Военный университет, 2005.

2. Землин А. И., Петров Ю. И., Харламова Ю. А. Актуальные проблемы развития транспортного законодательства в России: Монография. - М.: Русайнс, 2019.

3. Осокин Е. Г. Внутренние таможенные пошлины в России. - Казань, 1850.

4. Сергеевич В. И. Древности русского права: в 3 т. - Т. 3: Земледелие. Тягло. Порядок обложения. Гос. публ. ист. б-ка России. - М., 2007.

5. Устав князя Ярослава о мостах // Российское законодательство X-XX веков. - В 9 томах. - Т. I. Законодательство Древней Руси. - М., 1984.

6. Соборное уложение 1649 года // Российское законодательство X-XX веков. - Т. 3. Акты земских соборов. - М., 1985.

7. Ключевский В. О. Сочинения. - В 9 т. - Т. 4. Курс русской истории. - М., 1989.

8. Полное собрание законов Российской империи. Собрание 1 - T. VI. -1720. - № 3615.

9. Семёнов А. Изучение исторических сведений о Российской внешней торговле и промышленности с половины XVII столетия по 1858 год. Часть первая. СПб., 1859.

10. Полное собрание законов Российской империи. Собрание 1 - Т. VI. -1722. - № 4025.

11. Полное собрание законов Российской империи. Собрание 1 - Т. XI. 1740. - № 8050.

12. Волков Л. В. Камер-коллегия // Государственность России (конец XV в. - февраль 1917 г.): Словарьсправочник. Кн. 2. - М.: Наука, 1999.

13. Полное собрание законов Российской империи. Собрание 1 - Т. VIII. -1731. - № 5711.

14. Макарова С. Л. Канцелярия перспективной дороги // Государственность России (конец XV в. февраль 1917 г.). Книга. 2. - М.: Наука, 1999.

15. Полное собрание законов Российской империи. Собрание 1 - Т. IX. -1734. - № 6536.

16. Полное собрание законов Российской империи. Собрание 1 - Т. XVI. -1764. - № 12053.

17. Полное собрание законов Российской империи. Собрание 1 - Т. XVIII. -1767. - № 12918.

18. Полное собрание законов Российской империи. Собрание 1 - Т. XX. -1780. - № 15074.

19. Полное собрание законов Российской империи. Собрание 1 - Т. XXI. -1782. - № 15334.

20. Полное собрание законов Российской империи. Собрание $1-$ T. XXIX. -1806. - № 22150.

21. Полное собрание законов Российской империи. Собрание 1 - Т. XXI. -1781. - № 15176.

22. Полное собрание законов Российской империи. Собрание 1 - Т. XXI. -1781. - № 15285.

23. Житков С. М. Исторический обзор устройства и содержания водных путей и портов в России за столетний период: 1798-1898. - СПб., 1900. 